\title{
Review of European Studies
}

\section{Comparison of the Convertible Bond Market Development in China and Europe and the Enlightenment}

\author{
Shengchun Zhu \\ Shenzhen Graduate School, Harbin Institute of Technology \\ Shenzhen 518000, China \\ Tel: 86-755-2600-8608 E-mail: zsc22@126.com
}

\begin{abstract}
As a financing tool with the characteristics of debt, stock, and option, convertible bonds have achieved a great development in Europe. China's convertible bonds market faces a series of problems, including public issuing, policy support for traditional industries, absence of short mechanism, and convergence of product design. China must summarize experiences from European market, apply support policies, and build a convertible market with sustainable development by means of perfecting the credit grading system, releasing the market entrance restrictions, encouraging innovations in product design and issuing ways.
\end{abstract}

Keywords: Convertible bond, Product innovation, Credit grading, Policy support

Convertible corporate bond, namely convertible bond for short, is issued in form of bond by legal procedures, and can be converted into stock under certain conditions. As one of main financial tools in world capital market, convertible bond has already gained fast development in USA and Japan. Chinese and European enterprises have started to use this financial tool since $90 \mathrm{~s}$ in $20^{\text {th }}$ century. Therefore, to summarize and compare the development of convertible bond in China and Europe is meaningful in practice.

\section{Compare the development of convertible bond market in China and Europe}

Europe is always one of main bond market in the world. Compared with USA and Japan, European investors emphasize on stable return. The coupon rate of convertible bond is lower than that of other bonds, which stops its development in Europe in a sense. Till early $80 \mathrm{~s}$ in $20^{\text {th }}$ century, American and Japanese enterprises begin to realize financing by issuing convertible bond in European bond market. Afterwards, England enterprises start this financing channel. But enterprises in Europe and China begin to use convertible bond as a financing tool in $90 \mathrm{~s}$ in $20^{\text {th }}$ century. Dortmunder Verein issues 390,000 convertible bonds for the first time, which pioneers the financing by convertible bonds in Europe. The deepening integration of European economy makes convertible bonds circulate in EU market. The issuer of convertible bonds can get considerable capitals in a short period, which drives the prosperity of European convertible bonds. In 1997, the market scale of convertible bonds in Europe is 65.6 billion US dollars, accounting for $16 \%$ of global market shares. In 1999, the scale reaches 124 billion US dollars, accounting for $26.22 \%$ of global market shares. In 2000 , the percentage reaches $31 \%$. European convertible bond market becomes the No.2 in the world. As a most free financial market in the world, Europe has already become one of most important convertible bond market in the world, no matter what it is evaluated by the new bond circulation, the market depth, or the degree of specialization. European convertible bond market mainly centers in France, German, and Switzerland. Especially, France has issued the great amount of convertible bonds in Europe.

China's capital market starts too late. Its development is no more than 20 years. In China, the capital market is a product 
of financial innovation. But convertible bond almost accompanies and victims the growth of A share market. In 1992, Shenzhen Baoan Group issues the first A-share convertible bond, which signalizes the birth of convertible bond in China. In 1993, China Textile Machinery and CSG holding were formally approved to issue convertible bonds in foreign countries, which is the fist of connecting China and foreign capitals together with B share. Up to now, China's convertible bond experiences the pilot stage (1992-2001), the re-start stage after approval (2001-2002), and the fast growth stage (2003-now). By analyzing its evolvement, we know that the prosperity of convertible bond in China associates closely with policies and regulations. On April $28^{\text {th }}, 2001$, China Securities Regulatory Commission releases the Issue of Convertible Bonds by Listed Companies Implementing Procedures, and later issues the Notice for Issue of Convertible Bonds by Listed Companies, loosing policy restrictions on the issue of convertible bonds. Afterwards, the issue of convertible bonds grows fast and turns into the most important re-financing tool in domestic capital market.

As a combination of common bond and call option, convertible bond has the characteristics of stock, bond, and option. For investors who hate risks but desire for interests from stocks, convertible bond is an attracting choice. For China's listed companies, convertible bond supplies a re-financing way. Therefore, convertible bond has a wide development space in China. According to statistical data from WIND, till March 31 ${ }^{\text {st }}, 2009$, China issues 61 convertible bonds. 44 of them have already exit from the market. Only 17 convertible bonds still circulate in the market. These convertible bonds collect 114.437 billion RMB. Since early this year, along with the expansion of fluidity and the support of policy, Ashare market rebounds strongly. Driven by the rise of A-shares, convertible bond market rises fast. Holders' arbitrary activities make the stock in convertible market to decrease significantly. The short of convertible bonds causes the rise of convertible bond price. It is predicted that convertible bond will be permitted to issue again in this year.

\section{Main problems in China's convertible bond market}

\subsection{Convertible is issued by public offering, which stops the expansion of market space.}

At present, the issue of convertible bond in China is carried out by public offering. From the corporate board and shareholders conference, to media institutions, to various preparations, to final approval by China Securities Regulatory Commission, the issue of convertible bond needs at least one year. It is time consuming on one hand. On the other hand, it may affect the effectiveness of some convertible bond items designed by enterprises in application. What's more important, the financing only by public offering but no private offering excludes most non-listed companies, especially fast-growth companies, which is not good for the development of convertible bond market. Foreign countries adopt both public and private offering in general. The issuer can make choice based on self conditions, which will benefit the enterprise's commercial operation and economic growth.

\subsection{Conditions for issue are good for traditional industry enterprises but not for new economy growth.}

Foreign experiences prove that an enterprise has two motives for issuing convertible bonds, namely low-rate financing and postponing-equity-premium financing. Therefore, convertible bond is right for small growing enterprises that have increasing demand for financing but the higher risks restrict the scale. So, the active enterprises in European convertible bond market are from fast-developed and newly-appeared industries, such as electric communication, science \& technology, medicine, biological science \& technology, finance, media, and Internet. Rules regulate that the issue of convertible bonds by Chinese enterprises focuses on listed companies that are profitable in recent three years and the average of net assets profit margin should be above $10 \%$. Therefore, Chinese enterprises that issue convertible bonds are mostly from traditional industries, such as steel, machinery, motor, and capital construction. More SMEs, fast-growing scientific and technological enterprises, and non-listed companies have no chance for issuing convertible bonds. This policy only encourages excellent enterprises to issue convertible bonds and sets strict regulations on non-listed companies and low-profit enterprises, which is not good for the long-term development of convertible bond market and the expansion of trade scale. It even hurts the sustainable development of economy and the adjustment of economic structure.

\subsection{Absence of a short mechanism makes institutional investors fail to carry out the arbitrage statistic.}

Convertible bond has the characteristics of bond and stock. Converting the option makes the market to overrate the expected issue price of stock and has the possibility of obtaining premium. Therefore, investors can get relatively stable interests and also return from dynamic trade by arbitrary. And risks are lower. However, there is not a short mechanism 
in China. The unilateral holding decreases the attraction of convertible bond for investors, especially institutional investors.

\subsection{Domestic convertible bond products are designed similarly, lacking of innovation.}

At present, the type of convertible bond is few in China's convertible bond market, only common convertible bond with interests and convertible bond by separate transaction. The design mode is similar. In recent years, the interest rate is close to $0.8 \%$. And the premium from converting into stocks fluctuates heavily along with the stock market. In Europe and other oversea market, the premium can reach $15 \%$ and $30 \%$, mostly between $20 \%$ and $25 \%$. Besides, domestic convertible bond is usually supported by unlimited downward amendment articles. Rules regulate that as the issue price of stock is lower than the conversion price by certain ratio (usually $80 \%$ or so), the enterprise can adjust the conversion price unlimitedly. So, enterprise managers can adjust the conversion price if necessary. It could not protect small and medium shareholders, which conflicts with present laws and regulations.

From relevant experiences in the world, in order to satisfy different investors' needs, the world market, including European market, makes continuous innovations. It covers many types, such as zero-interest convertible bond, common convertible bond (high-interest or high premium, premium re-purchase, and multiple purchases), pre-sell convertible bond before listing, convertible bond with priority, and compulsory convertible bond. Although the convertible bond with interests is still the main body, zero- interest convertible bond rises fast, which accounts for $21.8 \%$ of market share in convertible bond market. In designing the conditions for conversion, there is no special complex amendment article for conversion price. The adjusted conversion price should not be lower than $80 \%$ of initial price of stock. And the adjustment is restricted under certain times. On one hand, it protects the interests of original shareholders. On the other hand, it can help to evaluate the price of convertible bond. Besides, traditional convertible bond takes a single stock as the base. Now more and more takes the stock price as the base. Convertible bond is not only a tool for financing. By using the arbitrary model, it has the function of controlling risks.

\section{Prospect for China's convertible bond market development}

All listed companies in China, no matter they are state-owned or not, are restricted in budgeting. They have a strong desire for financing. In China's capital market, because the convertible bond is regarded as a "financing related with equity", it wins welcome of listed companies. Compared with other financing methods, it has more merits. Firstly, the pressure for excellent performance is small. To issue convertible bond gives a cushioning period for the rise of stock price. It can release the pressure on some key performance indexes, such as earnings per share, and return on net assets. Secondly, cost of financing is lower. The interest rate of convertible bond decreases from early $1.6 \%$ to $0.8 \%$ gradually, which is lower than the interest rate of banks and also that of common convertible bond significantly. Thirdly, the efficiency of financing is higher. The conversion price of convertible bond is permitted to be higher to certain degree than the average of 30 trade days before the public introduction. The price of newly-issued stock is determined by the discount principle. As a result, the financing per stock is higher. These factors make convertible bond more attractive for issuers. But as for how to protect investors' interests, insure information transparency, and build sustainable development convertible bond market, relevant sectors, especially the regulatory and supervision institutions, should participate in this process actively. Here, the key is always the government's support and direction.

\subsection{Perfect the credit grading system and insure information transparency}

Convertible bond belongs to the scope of derivative securities. Its pricing and issuing are very complex. Because issuers and securities dealers always take the financing as the priority in designing conversion conditions, investors must firstly evaluate a project's interests and risks completely, such as risks of rates, re-purchase risk, decline of stock price, and failure in conversion. According to successful world experiences, American, European, and Japanese markets evaluate the credit of enterprises that issue convertible bond. The rate of convertible bond and the premium of conversion are determined by the credit of convertible bond. In Europe, as a relatively conservative investment market, enterprises' credit evaluation is necessary. However, in China, the credit grading on convertible bond is still on the starting stage. The perfection and reliance of credit grading system have not gained a wide recognition of market. In order to insure the safety of convertible bond investment, China mainly adopts the way of offering guaranty for insuring. It is urgent to build and perfect the credit grading system. At present, foreign capitals are rushing into the credit grading market. Among the five credit grading enterprises in China, four of them have been controlled directly or indirectly by foreign 
capitals. In the future, regulations on the sell, the issue, and the approval of convertible bond, and the information disclose will be stricter. Requirements for effective regulatory and supervision on credit grading institutions will be higher in order to defending the issuing enterprise and the credit grading institution hurting investors of convertible bond.

\subsection{Loose the market entrance conditions and encourage growing enterprises to issue convertible bonds}

China has ever regulated strict restraints on enterprises issuing convertible bond. Taking the net assets and other financial indexes as the issue standards is too simple. Policies mainly support large enterprises at the mature stage in traditional industries. It seldom considers the project. The management level should focus on examining the project instead of the issue enterprise. It is better to support the highly-growing enterprises instead of large enterprises, improving domestic enterprises' independent innovation capabilities. Therefore, China adjusts some issue indexes, such as the net assets and the asset-liability ratio, encouraging high-tech enterprises to issue convertible bonds, which is in accordance with China's policy of encouraging innovation and changing economic growth way, offering a wider market space for the development of convertible bond.

\subsection{Encourage innovation of product design and issue way}

Domestic convertible bond market has developed for more than one decade. Conditions for issuing different types of convertible bonds are mature. The state should encourage issue enterprises to produce new convertible bond with different features by changing specific articles based on common convertible bond, and gives it priority of approval. Firstly, prolong the issue term of convertible bond gradually. In China, the shortest term of convertible bond is three years, and the longest is five years, which is far shorter than that of foreign countries, mostly are above ten years. It may force enterprises to take short-term action in choosing financing project, which will harm the enterprises' long-term development. Secondly, permit the co-existence of public offering and private offering. Based on summarizing the successful experiences in world mature markets and domestic market conditions, China can make up regulations on private offering, decreasing the issue cost and perfecting the issue way. Thirdly, institutional investors are growing. Statistical data show that institutional investors hold $90 \%$ of convertible bond circulating in the market. Because investors have strong abilities of defending risks, some institutional investors or enterprises can not only get interests by price difference in trading convertible bonds, but also get an enterprise's controlling right quietly by purchasing amounts of convertible bonds. However, only the enterprise with excellent performance can issue the convertible bond with interests, which can not satisfy different investors' preferences for risks. China should make innovations on relevant regulatory and supervision policies, balancing the interests of different parties in the market, and driving the development of convertible bond market in China.

\section{References}

Cao, Kai. (2008). Why listed company likes convertible bonds. China urban and rural financial news. $26^{\text {th }}$, Feb.

Kong, Fanjun. (2001). Convertible bonds markets in Europe and North America. Securities Market Herald, No.11.

Tang, Jing \& Li, Xiaoxiao. (2007). An empirical study of convertible bonds turning into stocks. Finance \& Economy, No.6.

$\mathrm{Xu}$, Tao \& Xu, Yuanbiao. (2006). China and foreign country's changeable bond market development situation and characteristics analysis. Special Zone Economy, No.1.

Yang, Kangyu. (2002). Development of overseas convertible bonds markets and its lessons to China. Securities Market Herald, No.6. 